\title{
A TECHNICAL STUDY OF MODIFIED GILLNET IN KENDAL REGENCY WATERS
}

\author{
Nurjanah Dhiyah Aprilia Dwi ${ }^{\star}$, Fitri Aristi Dian Purnama, Wijayanto Dian \\ Coastal Resources Management Program, Department of Fisheries, Faculty of Fisheries and \\ Marine Science, University of Diponegoro, Indonesia \\ *E-mail: dhiyah april@yahoo.co.id
}

\begin{abstract}
Gillnets are the fishing gear selected by Kendal fishermen particularly in small-scale artisanal fisheries because gillnets need relatively small capital, have easy operation, use medium- or small-sized fishing vessels, and are selective towards catches. Modifications were made by increasing the performance of the fishermen gillnet to get more economical fish catches. This study aims to technically analyze the modified gillnet on the catch composition. The study was conducted in Kendal waters in April 2019 with a 1 GT vessel using a comparative design with experimental fishing. The modified gillnet was a net made from PA multi-monofilament of $0.20 \times 10$ ply with 4-inch mesh size with the specifications of the mounted length of netting of 50 meters and the mounted height of netting of $5.9 \mathrm{~m}$ for one net with a hanging ratio of 0.55 . Based on the paired sample t-test results, $t_{\text {count }}$ value $=7.690$ is greater than $t_{\text {table }}(0.05)=$ 1.796. $\mathrm{H}_{0}$ is rejected and $\mathrm{H}_{1}$ which states that there is a difference in the number and weight of fish caught by the fishermen gillnet and the modified gillnet is accepted. Dominant species caught by the modified gillnet were Euthynnus affinis which were mostly allowable to catch both caught by the fishermen gillnet (51\%) and the modified gillnet (95\%) and Scromberomorus commersoni which were mostly not allowable to catch both caught by the fishermen gillnet (89\%) and the modified gillnet (64\%).
\end{abstract}

\section{KEY WORDS}

Gillnet, modification, Kendal, technical specifications, allowable to catch.

Utilization of fish resources in Kendal Regency waters is still dominated by small-scale fishing using various kinds of fishing gears, such as bottom gillnets, danish seine, fish traps, gillnets, mini bottom trawls, mini purse seines, and seine nets (Pratiwi and Rahardjo, 2017). Gillnets are a mainstay fishing gears in Kendal fishing community. Based on previous study conducted by Pratiwi and Rahardjo (2017), catch composition of the fishermen gillnet in Kendal waters showed that around $15 \%$ types of demersal fish were caught. It was due to the fishing operation area in shallow waters of $15-30 \mathrm{~m}$ with a quite high net height of 11-13 $\mathrm{m}$, causing a high catch of demersal fish. Therefore, to limit the target and increase fish catches, the fishermen's gillnet were modified. Modifications were made by increasing the performance of the fishermen gillnet to get more economical fish catches.

Getting a lot of catches is an expectation of local fishermen. However, if marine resources are captured continuously without regard to allowable-to-catch fish, the catches will be increasingly reduced because gonadal immature fish have no time to breed. Therefore, technical analysis calculations are needed in order to create a gillnet with large catches, yet remains selective to maintain marine sustainability. Effective and selective fishing methods can reduce current overfishing. Catching accuracy is expected to increase fishermen's income.

Thus, a more in-depth study of the modified gillnet in terms of design, construction, and selectivity is needed. This study aims to technically analyze the modified gillnet on the catch composition in Kendal waters.

\section{METHODS OF RESEARCH}

This study was conducted in April 2019 in Kendal waters at positions between $\mathrm{S} 060^{\circ}$ 47,536 '- S $06^{\circ} 52,658^{\prime}$ and E $109^{\circ} 00,559$ '- E $110^{\circ} 57,467$ ' with a depth of between 15 30 meters. 
The method used in this study was a comparative design with experimental fishing conducted in Kendal Waters, i.e. by comparing the trial of fishing operations using the fishermen gillnet and the modified gillnet.

To find out the technical criteria for the modified gillnet construction, calculations of the hanging ratio, the net height, the buoyant and sinking forces were conducted using the following formula (Prado, 1991):

$$
E_{L a}=\frac{L_{a}}{L_{0 a}}
$$

Where: $E_{l a}$ - above hanging ratio; $L_{a}$ - above mounted length of netting; $L_{0 a}$ - above stretched length of netting.

Vertical hanging ratio $\left(\mathrm{E}_{\text {vertical }}\right)$ :

$$
E_{\text {tegak }}=\sqrt{1-E_{L a}^{2}}
$$

The position of the net in the water can be calculated using the following formula:

$$
h=H \sqrt{1-E_{\text {tegak }}^{2}}
$$

Where: $\mathrm{h}$ - Mounted height of netting; $\mathrm{H}$ - Stretched height of netting; $\mathrm{E}$ - Hanging ratio mean.

Gillnet basic construction has the buoyant and sinking forces so that the net can stretch vertically in the water. The buoyant and sinking forces can be calculated using the following formula:

$$
B_{1}=W\left(\frac{\partial_{s w}}{\partial_{w}}-1\right)
$$

Where: B1 - Buoyant force of component (kgf); W - Weight of component in air (kgf); $\partial_{\mathrm{w}}$ : Density of component $\left(\mathrm{gr} / \mathrm{cm}^{3}\right) ; \partial_{\mathrm{sw}}$ - Density of seawater $\left(\mathrm{gr} / \mathrm{cm}^{3}\right)$.

$$
S_{1}=W_{n}\left(1-\frac{\partial_{s w}}{\partial_{w}}\right)
$$

Where: S1 - Sinking force of component (kgf); W - Weight of component in air/volume (kgf); $\partial_{\mathrm{w}}$ - Density of component $\left(\mathrm{gr} / \mathrm{cm}^{3}\right) ; \partial_{\mathrm{sw}}$ - Density of seawater $\left(\mathrm{gr} / \mathrm{cm}^{3}\right)$.

Data on collected catches was analyzed using descriptive comparative analysis by knowing the type, number, and characteristics as well as their relation to water conditions. Meanwhile, to find out the differences between treatments, an analysis was performed using the Paired sample t-test. According to Sugiyono (2006), the Paired sample t-test is a different test of two samples in pairs. Paired samples are the same subject but experience different treatments, with the following analysis:

$\mathrm{H}_{0}=$ It is suspected that there is no difference in catches between the fishermen gillnet and the modified gillnet;

$\mathrm{H}_{1}=\mathrm{It}$ is suspected that there is a difference in catches between the fishermen gillnet and the modified gillnet;

If $t_{\text {count }}>t_{\text {table }}$ then $\mathrm{H} 0$ is rejected and $\mathrm{H} 1$ is accepted;

If $t_{\text {table }}>t_{\text {count }}$ then $\mathrm{H} 1$ is rejected and $\mathrm{HO}$ is accepted.

Gillnet selectivity test analysis was conducted by performing the length data collection which was then entered into the pre-determined class interval, then entering the frequency of 
each class so that the mean length at first capture/Lc was obtained. Estimation of $L c$ or $L_{50 \%}$ was done by make a "logistical curve" graph i.e. the relationship between the length of the fish $(x)$ and the number of fish expressed by the cumulative percentage $(y)$ to form a Sigmoid shaped curve. Data were analyzed using the selectivity formula (Sparre, P \& S.C. Venema in Anggareini et al., 2017):

$$
F(c)=\left(\frac{n d L}{s \sqrt{2 \pi}}\right) e^{-\frac{\left(L^{\prime \prime}-L\right)^{2}}{2 S^{2}}}
$$

Where: $F(c)=$ the frequency of fish in a length class; $n=$ number of samples in the sampling; $\mathrm{dL}=$ length class interval; $\mathrm{s}=$ standard deviation; $\pi=$ constant $3.14 ; \mathrm{L} "=$ mid-length class value; $L=$ the mean length of one fish cohort.

Furthermore, the estimation of the mean and standard deviation of fish length in each sample was done by changing the equation in linear form as follows:

$$
\Delta \operatorname{lnFc}(\mathrm{z})=a-b x\left(L+\frac{d L}{2}\right)
$$

Where: $\Delta \operatorname{lnFc}(z)=$ logarithm difference of two length classes; $L+d L / 2=$ the upper limit of each class length; $a, b=$ constants.

The mean and standard deviation values of fish length in each particular age group were estimated using the following formula:

$$
L_{C}=\frac{a}{b} \text { and } s^{2}=-\frac{d L}{b}
$$

Then, the comparison between the Lc value and the Lm (length at first maturity) value was conducted.

The following are the technical specifications of the fishermen gillnet and the modified

\begin{tabular}{|c|c|c|c|}
\hline \multirow{2}{*}{ No } & \multirow{2}{*}{ Description } & \multicolumn{2}{|l|}{ Size (1 piece) } \\
\hline & & Fishermen Gillnet & Modified Gillnet \\
\hline A. & Size / dimension & & \\
\hline 1 & Stretched length (meter) & 100 yard / 91.44 & 100 yard / 91.44 \\
\hline 2 & Mounted length (meter) & 46 & 50 \\
\hline 3 & Net height (mesh) & 140 & 70 \\
\hline B. & Net body & & \\
\hline 1 & Mesh size (inch / mm) & $4 / 101.6$ & $4 / 101.6$ \\
\hline 2 & Net material & PA Multi-Monofilament & PA Multi-Monofilament \\
\hline 3 & Number of yarns & $0.20 \times 10$ ply & $0.20 \times 10$ ply \\
\hline C. & Rigging & & \\
\hline 1 & Head rope & $\mathrm{PE} \varnothing 7 \mathrm{~mm}$ & $\mathrm{PE} \varnothing 7 \mathrm{~mm}$ \\
\hline 2 & Float line & $\mathrm{PE} \varnothing 7 \mathrm{~mm}$ & PE $\varnothing 7 \mathrm{~mm}$ \\
\hline 3 & Sinker line & $\mathrm{PE} \varnothing 3 \mathrm{~mm}$ & $\mathrm{PE} \varnothing 3 \mathrm{~mm}$ \\
\hline D. & Floats & & \\
\hline 1 & Material / type & PVC, Y-8 & PVC, SH3 \\
\hline 2 & Number of floats & 22 & 61 \\
\hline 3 & Distance between floats $(\mathrm{cm})$ & 255 & 83 \\
\hline E. & Sinkers & & \\
\hline 1 & Material & Lead & Lead \\
\hline 2 & Number of sinkers & 5 pieces @ 500 gr & 4 pieces @ 500 gr \\
\hline 3 & Distance between sinkers(mesh) & 225 & 112 \\
\hline $\mathrm{F}$. & Additional floats & & \\
\hline 1. & Material & PVC, bottle type & Styrofoam \\
\hline 2. & Number (pieces) & 3 & 9 \\
\hline
\end{tabular}
gillnet used in the study:

Table 1 - Gillnet specifications 


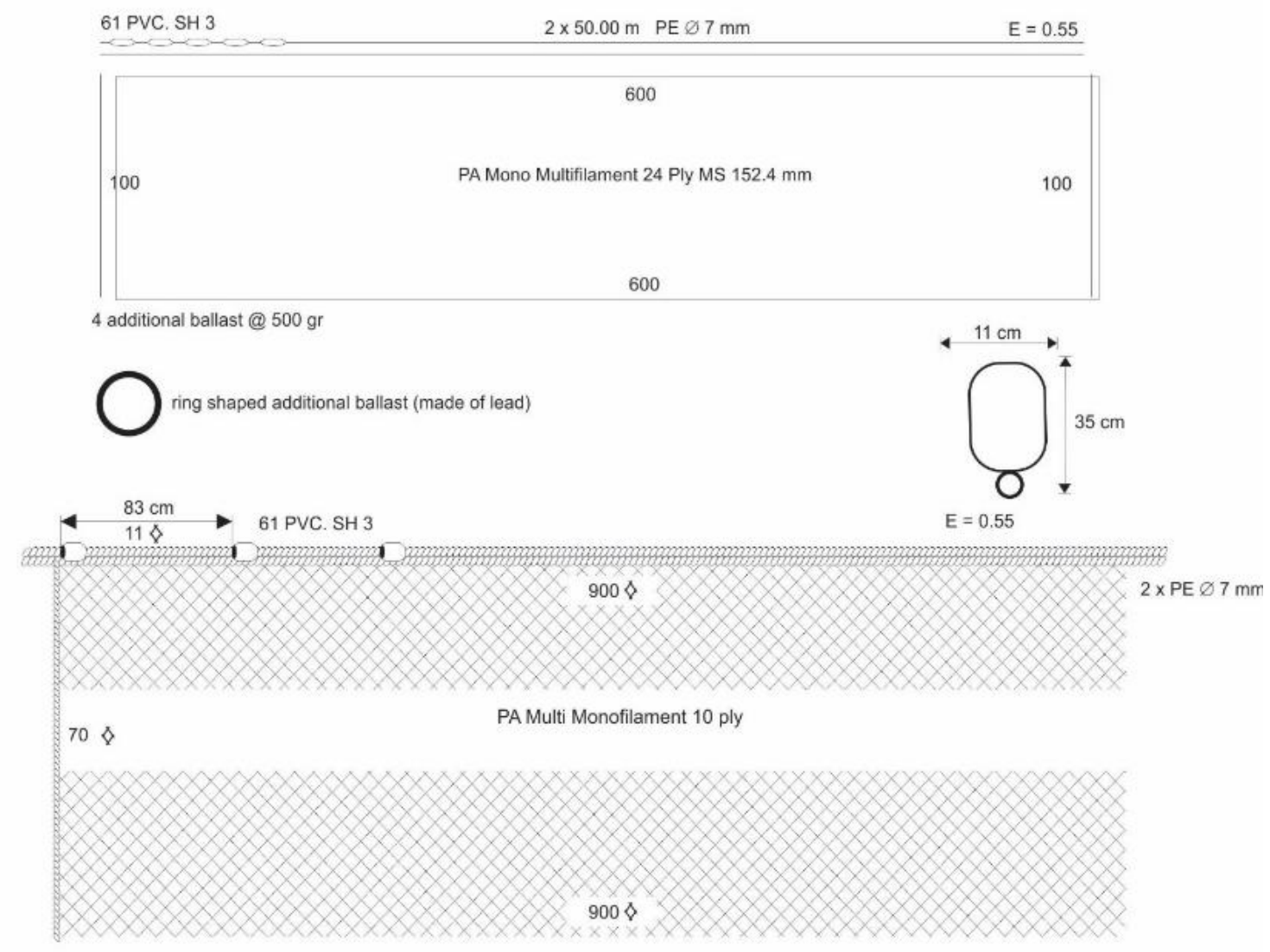

additional life rope $10.00 \mathrm{PE} \emptyset 5 \mathrm{~mm}$,

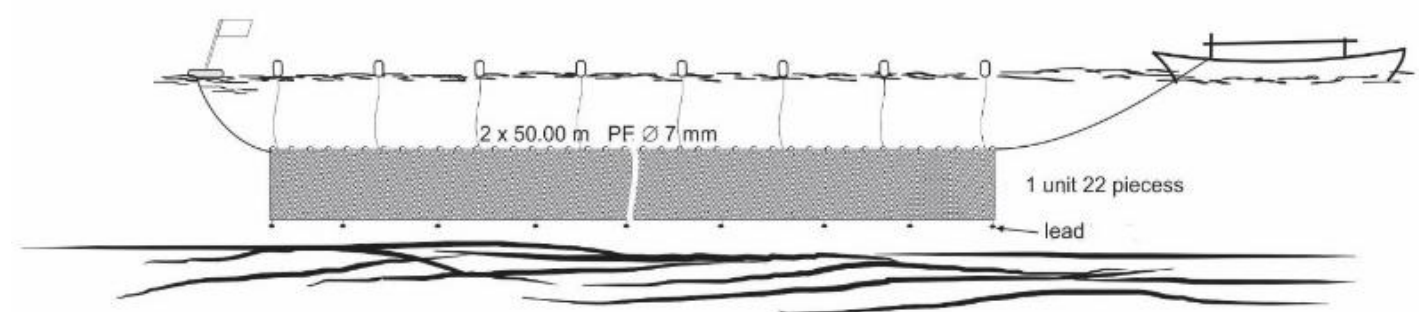

Figure 1 - Design of the Modified Gillnet PA Multi-Monofilament of $0.20 \times 10$ ply; 4 inch

\section{RESULTS AND DISCUSSION}

Kendal Regency waters are one of the most potential demersal and pelagic fish distribution areas in the northern waters of Central Java. Diverse fish resource potentials include small pelagic fish, large pelagic fish, demersal fish, reef fish, hard skin animals (crustaceans), soft skin animals (mollusks), and other aquatic animals. Based on Kendal Regency Fishery Statistics Data in 2018, the total production of Kendal Regency fisheries was 2,762 tons with a production value of IDR $27,749,713,000$. Small pelagic fish dominated the production of 1,850.54 tons, followed by large pelagic fish production of 138.1 tons, demersal fish of 745.74 tons, and other fish of 27.62 tons. Large pelagic fish utilization was not optimal when compared to small pelagic fish utilization.

A gillnet is a mounted perpendicular net in the water to block the fish swimming direction. Targets species of gillnet are pelagic fish and/or demersal fish, depending on the gillnet position stretched in the water column. Based on observations, fish are caught by being enmeshed in the netting or entangled in the net body. If the fishing gear catches a lot of fish by entangling, the mesh as trappers cannot function properly. Fishes larger or smaller than the mesh can be caught in the net without having to penetrate the mesh (Razak et al, 
2014). The modified gillnet is a gillnet operated in the middle of the water column to catch pelagic fish.

Gillnets components according to SNI 01-7215-2006 are as follows:

1. A float line is a rope used to place and tie floats;

2. A float is an object which has the buoyant force, is attached on the upper net, and functions as a float for the net;

3. An upper selvedge line is a rope located between the float line and the head rope functioning as a reinforcement of the upper net rope;

4. A head rope is a rope used to hang the net body;

5. An upper selvedge is a sheet of netting attached above the net body functioning as a reinforcement of the upper net body;

6. A net body is a rectangular sheet of netting with equal or even mesh size;

7. A lower selvedge is a sheet of netting attached under the net body functioning as a reinforcement of the bottom net body;

8. A side line is a rope attached to the sides of the net body functioning as a gillnet height limits;

9. A ground rope is a rope used to limit the movement of the net to the side;

10. A lower selvedge line is a rope located between the ground rope and the sinker line functioning as a reinforcement of the bottom net rope;

11. A sinker line is a rope used to place and tie sinkers;

12. A sinker is an object which has the sinking force, is attached on the bottom net, and functions as a sinker for the net.

Gillnet technical analysis was directed to calculations related to the hanging ratio or elongation, the mounted height of netting, and the comparison of the buoyant and sinking forces. These calculations were very necessary to examine the technical feasibility of the design and to provide recommendations for the gillnet to work optimally. The following are the gillnet technical calculations adjusted to the SNI 01-7215-2006 technical provisions on the standard form of multifilament surface gillnet construction without recommendation:

Table 2 - Technical calculations of the fishermen gillnet and the modified gillnet

\begin{tabular}{lllll}
\hline \multirow{2}{*}{ No. } & \multirow{2}{*}{ Component } & \multicolumn{2}{l}{ Calculation Value } & \\
\cline { 3 - 4 } & & Fishermen & Modified & SNI 01-7215-2006 \\
\hline 1 & Hanging ratio (Elongation) & 0.5 & 0.55 & $0.50-0.65$ \\
2 & Mounted height (h) & 12.23 meter & $5.9 \mathrm{~meter}$ & - \\
3 & Yarn diameter $(\mathrm{dt})$ & $0.2 \mathrm{~mm}$ & $0.2 \mathrm{~mm}$ & $0.1-1.8 \mathrm{~mm}$ \\
4 & Buoyant \& sinking forces & & & \\
& - Head rope & $0.080(-)$ & $0.092(-)$ & \\
& - Float line & $0.080(-)$ & $0.092(-)$ & \\
& - Sinker line & $0.010(-)$ & $0.017(-)$ & \\
& - Net & $1.160(+)$ & $0.580(+)$ & \\
& - Floats & $1.760(-)$ & $1.708(-)$ & \\
& - Sinkers & $2.270(+)$ & $1.800(+)$ & \\
5 & Comparison of buoyant \& sinking forces (W per B) & 1.178 & 1.25 & $1.20-1.45$ \\
\hline
\end{tabular}

Based on the above table, it can be seen that the modified multi-monofilament gillnet of 10 ply; 4 inch was in accordance with or was still in the range of SNI 01-7215-2006. The elongation value of modified gillnet was 0.55 . The increased hanging ratio was intended to open the mesh wider. A higher hanging ratio results in wider openings in the mesh with lower slack levels. Conversely, a smaller hanging ratio will result in lower net openings with higher slack levels. Higher net slack will increase the entanglement of the net against the catches (Prado, 1991).

According to Al Hizaz's research (2011), the higher entanglement in the bottom gillnet with a hanging ratio of 0.45 had an impact on the total number of fish caught in the bottom gillnet. The compositions of Decapterus spp catches by the bottom gillnet were $73 \%$ of fish was entangled, $16 \%$ of fish was wedged, and $11 \%$ of fish was gilled. The smaller the hanging ratio was, the more fish would be caught and the fish were entangled. It means that the gillnet was not selective. The hanging ratio was ineffective in gillnet selectivity. Therefore, by 
increasing the hanging ratio of 0.55 , the modified gill net was expected to catch large fish only.

The modified gillnet height was $5.9 \mathrm{~m}$. Net body cutting from 140 mesh into 70 mesh was conducted. It aimed to adjust to the depth of the fishing ground area ranged only between 15-30 $\mathrm{m}$ and was in accordance with the swimming layer of the catch target i.e. Euthynnus affinis and Scromberomorus commersoni fish. Based on previous study conducted by Pratiwi and Rahardjo (2017), catch composition of the fishermen gillnet in Kendal waters showed that around 15\% types of demersal fish were caught. It was expected that net body cutting allowed a high pelagic fish catches.

The comparison of the buoyant and sinking forces of the modified gillnet was 1: 1.25. The comparison of the buoyant and sinking forces shows the net position on the water surface. Net position is determined by stretch tension of the net body. According to Ayodhyoa (1981) in Al Hizaz (2011), stretch referred to here is stretch in the width as well as stretch in the length. This stretch tension will result in tension on the float line and the net body. If the net is stretched too tight, then the fish will be difficult to get entangled and the entangled fish will easily escape. The stretch tension of the net body will be determined primarily by the buoyant force of floats, the net body weight, the rigging, the sinking force of sinkers, and the shortening used.

The net mesh size of 4 inches $(101.6 \mathrm{~mm})$ was aimed for pelagic fish catch targets such as Euthynnus affinis and Scromberomorus commersoni. This is in line with the research results of Pratiwi, M (2010), Hantardi et al (2013), and Marliani (2016) stating that a gillnet with 4 inch/101.6 mm mesh size was used for pelagic fishing i.e. Euthynnus affinis and Scromberomorus commersoni.

Based on the technical analysis, the modified gillnet performance, in general, can be operated properly. The setting process took around 30 minutes. Floats on the gillnet can work well because they were able to withstand the sinking force of the net. It means that the buoyant force worked well as was shown when the hauling was performed. The top of the net was not twisted and the position of the net body sheet stretched across the water column. Sinkers on the gillnet also worked well because they were able to offset the buoyant force, causing the net sheet to stretch across the water column. The hanging ratio of 0.55 made fish caught by being enmeshed or entangled. The captured fish were in accordance with the target, i.e. catching large-sized pelagic fish according to 4-inch mesh size.

Table 3 - Composition of gillnet catches

\begin{tabular}{|c|c|c|c|c|c|}
\hline \multirow[b]{2}{*}{ No. } & \multirow[b]{2}{*}{ Fish Species } & \multirow{2}{*}{$\begin{array}{l}\text { Fishermen Gillnet } \\
\text { Number } \\
\text { (fish) }\end{array}$} & \multicolumn{2}{|c|}{ Modified Gillnet } & \multirow[b]{2}{*}{$\begin{array}{l}\text { Weight } \\
(\mathrm{kg})\end{array}$} \\
\hline & & & $\begin{array}{l}\text { Weight } \\
(\mathrm{kg})\end{array}$ & $\begin{array}{l}\text { Number } \\
\text { (fish) }\end{array}$ & \\
\hline 1 & Formio niger & 2 & 0.74 & 1 & 0.56 \\
\hline 2 & Saurida tumbil & & & 1 & 0.15 \\
\hline 3 & Rhizoprionodon acutus & 1 & 0.87 & & \\
\hline 4 & Pomadasys maculatus & 21 & 11.28 & 2 & 1.32 \\
\hline 5 & Johnius trachycephalus & 2 & 0.25 & & \\
\hline 6 & Rastrelliger brachysoma & 14 & 0.75 & 28 & 1.3 \\
\hline 7 & Eleutheronema tetradactylum & & & 2 & 2.03 \\
\hline 8 & Istiophorus platypterus & & & 1 & 3.75 \\
\hline 9 & Trichiurus lepturus & 1 & 0.14 & & \\
\hline 10 & Arius thallassinus & 8 & 5.22 & & \\
\hline 11 & Lutjanus Mahogoni & 7 & 5.31 & 4 & 2.84 \\
\hline 12 & Chirocentrus dorab & & & 2 & 0.33 \\
\hline 13 & Dasyatis sp & 1 & 0.52 & & \\
\hline 14 & Leiognathus equulus & 5 & 0.76 & & \\
\hline 15 & Psettodes erumeri & 3 & 0.75 & & \\
\hline 16 & Selaroides leptolepis & 3 & 0.21 & 11 & 1.03 \\
\hline 17 & Scomberoides commersonnianus & & & 2 & 1.85 \\
\hline 18 & Scromberomorus commersoni & 45 & 47.6 & 94 & 194.41 \\
\hline \multirow[t]{2}{*}{19} & Euthynnus affinis & 39 & 29.82 & 58 & 87.85 \\
\hline & Total & 152 & 104.22 & 206 & 297.42 \\
\hline
\end{tabular}


The gillnet catch target was pelagic fish. There were 19 species of fish caught. Based on paired sample t-test results, the $t_{\text {count }}$ value $=7.690$ while the $t_{\text {table }}(0.05)$ value $=1.796$. From the significance test results, it was found that the $t_{\text {count }}$ value is greater than the $t_{\text {table }}$ value. Thus, it can be concluded that $\mathrm{H}_{0}$ is rejected and $\mathrm{H}_{1}$ stating that there is a difference in catches between the fishermen gillnet and the modified gillnet is accepted. The modified gillnet was able to catch more pelagic fish based on the number and weight of fish.

Composition of gillnet catches from the fishermen gillnet and the modified gillnet varied. However, selectivity testing required fish species often caught in both nets. Fish species often caught were Euthynnus affinis and Scromberomorus commersoni. The fish were used for selectivity analysis test material which showed the selectivity level between the two different hanging ratios. It is confirmed by Argent and Kimmel (2005) in Putri et al (2018) that all types of nets generally catch all fish species, but significantly different types of fishing nets catch more diverse fish species. Thus, the tested species are fish species often caught by all nets.

Selectivity testing was employed to see how much the number and size of fish caught categorized as allowable to catch. According to Sparre \& Venema in Anggareini et al., (2017), the less the number of catches is entangled, the more likely the fishing gear is selective. The number or proportion of fish caught with gillnet by being entangled highly determines gillnet selectivity. Thus, it is important to know the proportion of catch and the way fish are caught.

Table 4 - Measurement results of the length, weight, and girth of Scromberomorus commersoni fish

\begin{tabular}{llll}
\hline Measurement parameters & & Fishermen gillnet & Modified gillnet \\
\hline \multirow{2}{*}{ Fork length $(\mathrm{cm})$} & Size range & $35.40-79.00$ & $39.00-93.50$ \\
& Mode & 48.00 & 64.00 \\
& Mean & 48.99 & 65.55 \\
Weight & Size range & $510-2.780$ & $1.020-4.300$ \\
(gram) & Mode & 750 & 1.071 \\
& Mean & 2.000 & 2.068 \\
Girth & Size range & $16.00-28.50$ & $21.00-39.00$ \\
(cm) & Mode & 21.00 & 26.40 \\
\hline
\end{tabular}

Table 5 - Measurement results of the length, weight, and girth of Euthynnus affinis fish

\begin{tabular}{llll}
\hline Measurement parameters & & Fishermen gillnet & Modified gillnet \\
\hline \multirow{2}{*}{ Fork length $(\mathrm{cm})$} & Size range & $26.10-50.00$ & $26.00-55.50$ \\
& Mode & 31.20 & 45.00 \\
& Mean & 35.28 & 44.18 \\
\hline \multirow{2}{*}{ Weight } & Size range & $220-2.300$ & $290-2.500$ \\
(gram) & Mode & 410 & 1.300 \\
& Mean & 765 & 1.515 \\
\hline Girth & Size range & $17.00-32.00$ & $18.40-35.00$ \\
$(\mathrm{~cm})$ & Mode & 22.50 & 32.00 \\
& Mean & 23.15 & 28.39 \\
\hline
\end{tabular}

To determine the gillnet selectivity, an analysis of the proportion of allowable-to-catch fish was conducted, i.e. the estimation of the size of fish caught categorized as allowable to catch. The proportion of allowable-to-catch fish was known by measuring Lc using the fork length-frequency distribution and then being compared to the length at first maturity. This study did not calculate the $\mathrm{Lm}$ value of fish caught. The $\mathrm{Lm}$ values of mackerel and tuna were based on the $\mathrm{Lm}$ value of the references.

The results showed the Lc values of Scomberoides commersonnianus caught by the fishermen gillnet $(\mathrm{LC}=59.97 \mathrm{~cm})$ and the modified gillnet $(\mathrm{LC}=63.99 \mathrm{~cm})$ were smaller than the $\mathrm{Lm}$ value $(65-70.9 \mathrm{~cm})$. These results provided information that Scomberoides commersonnianus fishing using the gillnets was not good $(\mathrm{Lc}<\mathrm{Lm})$, because the mean of fish caught was in immature conditions. The gillnets were not selective against Scomberoides commersonnianus fish because they caught immature Scomberoides 
commersonnianus fish. Whereas, the Lc values of Euthynnus affinis caught by the fishermen gillnet $(\mathrm{Lc}=33.9 \mathrm{~cm})$ and the modified gillnet $(\mathrm{LC}=41.66 \mathrm{~cm})$ were greater than the $\mathrm{Lm}$ value $(33.7 \mathrm{~cm})$. It provided information that Euthynnus affinis fisheries were in good condition because of the value of $L c>L m$.

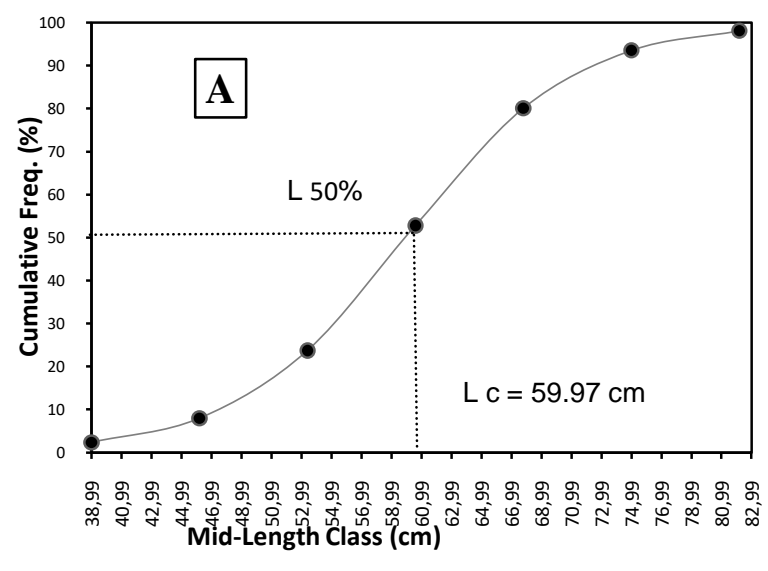

Fishermen gillnet

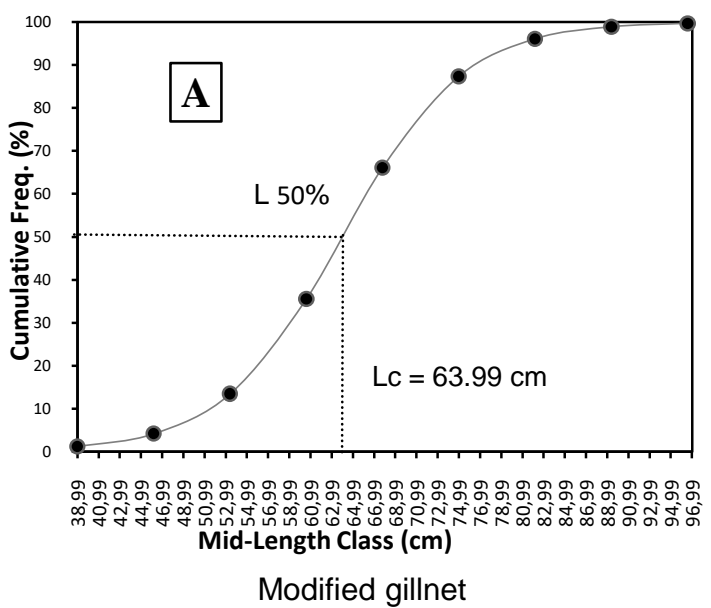

Modified gillnet

Figures 2 \& 3. Graph of Lc of Scomberoides commersonnianus caught by the gillnets

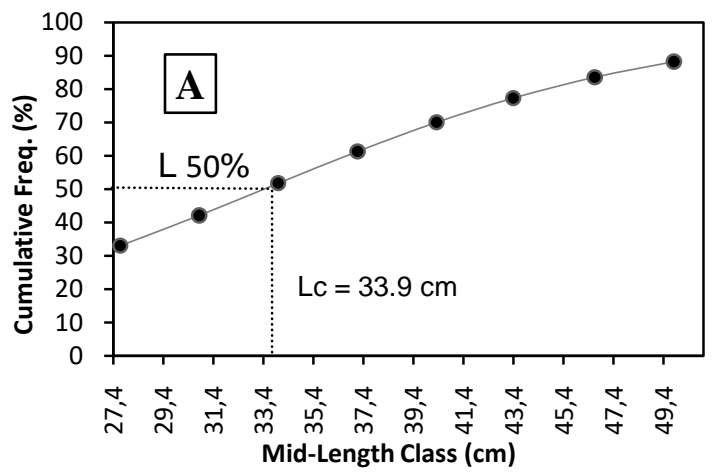

Fishermen gillnet

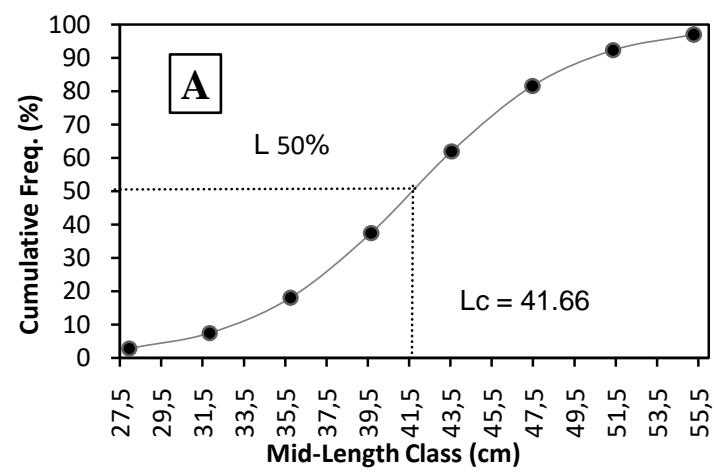

Modified gillnet

Figures 4-5 - Graph of Lc of Euthynnus affinis caught by the gillnets

Saranga et al (2019) stated that if the value of $L c<L m$, then the condition of fish resources is not good because it can lead to the growth of unhealthy fish stocks as a result of fishing pressure. If this condition is left continuously, it will endanger fish stock conditions because there is no recruitment process. This condition can be minimized by catching mature fish only. However, it is certainly a challenge for stakeholders in implementing the rules.

Table 6 - The size of fish caught compared to the $\mathrm{Lm}$ value of the references

\begin{tabular}{|c|c|c|c|c|}
\hline \multirow[b]{2}{*}{ Fish species } & \multicolumn{2}{|c|}{ Lc value $(\mathrm{cm})$} & \multirow{2}{*}{\multicolumn{2}{|c|}{$\begin{array}{l}\mathrm{Lm} \text { value }(\mathrm{cm}) \text { based on the } \\
\text { references }\end{array}$}} \\
\hline & $\begin{array}{l}\text { Fishermen } \\
\text { Gillnet }\end{array}$ & $\begin{array}{l}\text { Modified } \\
\text { Gillnet }\end{array}$ & & \\
\hline $\begin{array}{l}\text { Scomberoides } \\
\text { commersonnianus }\end{array}$ & 59.97 & 63.99 & $\begin{array}{c}65 \\
70.9 \\
85.0\end{array}$ & $\begin{array}{c}\text { Ramdhan (2008) } \\
\text { Boesono et al (2017) } \\
\text { www.fishbase.org }\end{array}$ \\
\hline Euthynnus affinis & 33.9 & 41.66 & $\begin{array}{l}33.7 \\
39.8\end{array}$ & $\begin{array}{c}\text { Hidayat et al (2018) } \\
\text { www.fishbase.org }\end{array}$ \\
\hline
\end{tabular}


Table 7 - Proportion of gillnet catch size

\begin{tabular}{|c|c|c|c|c|c|c|c|c|}
\hline \multirow{3}{*}{ Criteria } & \multicolumn{4}{|c|}{ Fishermen gillnet } & \multicolumn{4}{|c|}{ Modified gillnet } \\
\hline & \multicolumn{2}{|c|}{ Scomberoides commersonnianus } & \multicolumn{2}{|c|}{$\begin{array}{c}\text { Euthynnus } \\
\text { affinis }\end{array}$} & \multicolumn{3}{|c|}{ Scomberoides commersonnianus } & Euthynnus affinis \\
\hline & $\begin{array}{c}\text { Number } \\
\text { (fish) }\end{array}$ & $(\%)$ & $\begin{array}{c}\text { Number } \\
\text { (fish) }\end{array}$ & $(\%)$ & $\begin{array}{l}\text { Number } \\
\text { (fish) }\end{array}$ & $(\%)$ & $\begin{array}{c}\text { Number } \\
\text { (fish) }\end{array}$ & $(\%)$ \\
\hline$<\mathrm{Lm}$ & 40 & 89 & 19 & 49 & 60 & 64 & 3 & 5 \\
\hline$>\mathrm{Lm}$ & 5 & 11 & 20 & 51 & 34 & 36 & 55 & 95 \\
\hline Total & 45 & 100 & 39 & 100 & 94 & 100 & 58 & 100 \\
\hline
\end{tabular}

Based on the proportion of gillnet catch size for 2 (two) dominant species caught, Euthynnus affinis were mostly allowable to catch, both caught by the fishermen gillnet $(51 \%)$ and the modified gillnet (95\%). Scomberoides commersonnianus were mostly not allowable to catch, both caught by the fishermen gillnet (89\%) and the modified gillnet $(64 \%)$. It is in line with Boesono et al's (2017) research that most fish caught by the millennium gillnet in Pati waters were not allowable to catch. Because of the number of allowable-to-catch fish $<60 \%$, it can be said that the millennium gillnet was less environmentally friendly. Fish catching above the size at first maturity can provide opportunities for the target fish to reproduce and spawn before being caught.

The proportion of allowable-to-catch fish and the composition of the main target catch showed the gillnet selectivity. When the proportion of allowable-to-catch fish and the produced main catches is greater, then the fishing gear can be said to be selective in terms of species. According to Efkipano (2012) in Boesono et al (2017), fishing gear selectivity is the ability of fishing gear to catch target fish at a certain size and species during fishing operation. Regulation on fishing gear selectivity aims to optimize the sustainable use of fish resources including increasing catch value and protecting certain species. The target fish is determined by considering the minimum size or weight of the allowable-to-catch fish.

\section{CONCLUSION AND SUGGESTIONS}

The modified gillnet made from PA Multi Monofilament of $0.20 \times 10$ ply with 4-inch mesh size had technical specifications of a hanging ratio of 0.55 , mounted height of netting on the water column of 5.9 meters, the total buoyant force of $1.909 \mathrm{kgf}$, and the total sinking force of 2,380 kgf. Thus, the comparison of the buoyant and sinking forces was 1: 1.25 in accordance with the SNI 01-7215-2006 technical provisions on the standard form of multifilament surface gillnet construction without recommendation.

Based on the paired sample t-test results, $t_{\text {count }}$ value $=7.690$ is greater than $t_{\text {table }}(0.05)$ $=1.796 . \mathrm{H}_{0}$ is rejected and $\mathrm{H}_{1}$ which states that there is a difference in the number and weight of fish caught by the fishermen gillnet and the modified gillnet is accepted.

The gillnets were not selective against Scomberoides commersonnianus fish because they caught immature Scomberoides commersonnianus fish.

Dominant species caught by the modified gillnet were Euthynnus affinis which were mostly allowable to catch, both caught by the fishermen gillnet $(51 \%)$ and the modified gillnet (95\%) and Scomberoides commersonnianus which were mostly not allowable to catch, both caught by the fishermen gillnet (89\%) and the modified gillnet (64\%).

Suggestion that can be given is in designing new fishing gear oriented to increasing the number and weight of fish catches, the security and management of fish resources should be considered. For example, for Scomberoides commersonnianus and Euthynnus affinis fishing in Kendal waters, increasing the size of fish caught is performed by reducing the number of fishing trips or the number of fishing operations to $1 / 2$ or $1 / 3$ of the total fishing trips during the spawning season.

\section{REFERENCES}

1. Al Hizaz, 2011. Perbedaan Hanging Ratio Jaring Rampus terhadap Hasil Tangkapan Ikan Layang di Perairan Cisolok, Palabuhan Ratu. Bogor: Institut Pertanian Bogor. 
2. Anggreini, Alinda Putri., Septiana Sri Astuti, Irfan Miftahudin, Putri Inova Novita, Dewa Gede Raka Wiadnya. 2017. Uji Selektivitas Alat Tangkap Gillnet Millenium terhadap Hasil Tangkapan Ikan Kembung (Rastrelinger brachysoma). Journal of Fisheries and Marine Science Vol. 1 No.1.

3. Boesono, H., Wangsit Nugroho, Indradi Setiyanto. 2017. Analisis Keramahan Alat Tangkap Jaring Tenggiri (Gillnet Millenium) di Perairan Pati terhadap Hasil Tangkapan. Journal of Fisheries Resources Utilization Management and Technology. 6(2): 89-97

4. Dinas Kelautan and Perikanan Kabupaten Kendal. 2019. Statistik Perikanan Kabupaten Kendal tahun 2018. Kendal: Badan Pusat Statistik.

5. Haluan, C. C. Rakhmadevi, Ari Purbayanto, \& M. Fedi A. Sondita. 2011. Studi Mengenai Proses Tertangkapnya and Tingkah Laku Ikan Terhadap Gillnet Millenium Di Perairan Bondet, Cirebon. Marine Fisheries Vol. 3, No. 1, 7-13

6. Hantardi, Zulie; Asriyanto; Aristi Dian. 2013. Analisis Lingkar Tubuh and Cara Tertangkap Ikan Tenggiri (Scomberomorus commerson) dengan Alat Tangkap Jaring (Gill Net) dengan Mesh Size 4 Inchi and Hanging ratio 0.56. Journal of Fisheries Resources Utilization Management and Technology, 2(3), 253-262.

7. Hidayat, T., Noegroho, T., Chodrijah, U., 2018. Biologi Ikan Tongkol Komo (Euthynnus affinis) di Laut Jawa. Jurnal Pengelolaan Perikanan Tropis, 2(1): 30-36

8. Marliani, Lina. 2016. Tingkat Pemanfaatan Ikan Tenggiri (Scomberomorus commersoni) di Perairan Kabupaten Indramayu. Unpublished Thesis. Departemen Pemanfaatan Sumberdaya Perikanan. Fakultas Perikanan and IImu Kelautan. Institut Pertanian Bogor. Bogor.

9. Prado, J \& P.Y Dremiere. 1991. Petunjuk Praktis Bagi Nelayan. Translated by Fauzi, Zarochman, Nur Bambang, Dulgofar, and Baithur Sjarif. FAO. BPPI. Semarang

10. Pratiwi, B. C., Rahardjo, Oktavian. 2018. Uji Kinerja Jaring Insang Millenium di Kabupaten Kendal, Jawa Tengah. Jurnal Ariomma, 34(1), 1-13.

11. Pratiwi, Mira. 2010. Komposisi Hasil Tangkapan Ikan Pelagis pada Jaring Insang Hanyut dengan Ukuran Mata Jaring 3,5 and 4 inci di Perairan Belitung Provinsi Bangka Belitung. Unpublished Thesis. Departemen Pemanfaatan Sumberdaya Perikanan. Fakultas Perikanan and IImu Kelautan. Institut Pertanian Bogor. Bogor.

12. Razak, Abu Darda., Sepri, Mustasim, Muhfizar. 2014. Analisis Pengaruh Perbedaan Hanging Ratio pada Jaring Insang (Gillnet) terhadap Hasil Tangkapan Ikan. Jurnal Airaha, III(1), 01-09.

13. Saranga, R., Silvester S., Jerry K., Muh. Zainul A., 2019. Ukuran Pertama Kali Tertangkap, Ukuran Pertama Kali Matang Gonad and Status Pengusahaan Selar Boops di Perairan Bitung. Journal of Fisheries and Marine Research, 2(1), $67-74$

14. Rahman, D.R., Tiarso, I., Asriyanto. 2013. Analisis Bioekonomi Ikan Pelagis pada Usaha Perikanan Tangkap di Pelabuhan Perikanan Pantai Tawang Kabupaten Kendal. Journal of Fisheries Resources Utilization Management and Technology, 2(1), 1-10.

15. SNI 01-7215-2006. Bentuk Baku Konstruksi Jaring Insang Pertengahan Multifilament Tanpa Saran. Badan Standarisasi Nasional. 